\title{
Brucea javanica Leaf Extract Induced Apoptosis in Human Oral Squamous Cell Carcinoma (HSC2) Cells by Attenuation of Mitochondrial Membrane Permeability
}

\author{
Britanto Dani Wicaksono ${ }^{1}$, Enos Tangkearung ${ }^{2}$, Ferry Sandra ${ }^{3,4,5, *}$ \\ ${ }^{1}$ Research Institute, Yarsi University, Jl. Let. Jend. Suprapto, Cempaka Putih, Kav. 13, Jakarta, Indonesia \\ ${ }^{2}$ Department of Forest Product Technology, Faculty of Forestry, Mulawarman University, Jl. Ki Hajar Dewantara, Samarinda, Indonesia \\ ${ }^{3}$ Department of Biochemistry and Molecular Biology, Faculty of Dentistry, Trisakti University, Jl. Kyai Tapa No.260, Jakarta, Indonesia \\ ${ }^{4}$ BioCORE Laboratory, Faculty of Dentistry, Trisakti University, Jl. Kyai Tapa No.260, Jakarta, Indonesia \\ ${ }^{5}$ Prodia Clinical Laboratory, Prodia Tower, Jl. Kramat Raya No.150, Jakarta, Indonesia \\ *Corresponding author. E-mail: ferrysandra@gmail.com
}

Received date: Mar 13, 2015; Revised date: Apr 6, 2015; Accepted date: May 13, 2015

\section{Abstract}

B ACKGROUND: Brucea javanica extract has been reported to have anti-proliferative and cell death induction activities. B. javanica extract was reported to induce apoptosis through caspase cascade. Most of investigated B. javanica extracts were derived from seeds and fruits, or commercially available oil emulsion. Therefore we conducted a study on B. javanica leaf extract (BJLE) in oral cancer cells.

METHODS: $B$. javanica leaves were collected, identified, minced, dried, extracted with distilled ethanol at room temperature for 24 hours, filtered and evaporated. Resulted BJLE was stored at $4^{\circ} \mathrm{C}$. Human oral squamous cell carcinoma (HSC)-2 cells were fasted for 12 hours and treated with BJLE in various concentrations for 24 hours. Cells were then quantified with 3-(4,5-dimethylthiazol2-yl)-2,5-Diphenyltetrazolium bromide (MTT) assay, demonstrated with 4',6'-diamidino-2-phenylindole (DAPI) staining. To find out mitochondrial membrane permeability (MMP), mitochondrial membrane potential $(\triangle \Psi \mathrm{M})$ was analyzed.

RESULTS: BJLE reduced percentage of viable HSC-2 cells in a concentration dependent manner. BJLE induced apoptosis in HSC-2 cells. With treatment of $50 \mu \mathrm{g} / \mathrm{ml} \mathrm{BJLE}$, fragmented nuclei were seen. $\triangle \Psi \mathrm{M}$ of HSC-2 cells treated with $50 \mu \mathrm{g} / \mathrm{ml} \mathrm{BJLE}$ were shifted to the left, meaning that BJLE induced reduction of $\triangle \Psi M$ and attenuation of MMP.

CONCLUSION: Our results suggested that BJLE could induce apoptosis by attenuating MMP.

KEYWORDS: Brucea javanica, leaf, apoptosis, HSC-2, MTT, DAPI, mitochondria, permeability

Indones Biomed J. 2015; 7(2): 107-10

\section{Introduction}

Brucea javanica (L.) Merr. is an evergreen shrub belonging to Simaroubaceae family.(1) The seeds of $B$. javanica, named as Ya-dan-zi in traditional Chinese medicine, are listed in Chinese Pharmacopoeia for the treatment of dysentery, malaria, warts and corns.(1,2) B. javanica oil emulsion formulation has already been developed as commercially available drug for anti-tumor clinical applications in China, and its clinical indications include lung cancer, prostate cancer, and gastrointestinal cancer.(3-7)

$B$. javanica extract has been reported to have antiproliferative and cell death induction activities.(8-16) There were numerous cancer lines have been tested with $B$. javanica extract, including breast cancer cell lines, such as MCF-7 (8-10), HTB126 (9) and MDA-MB231 (11); cervical cancer cell lines, such as CaSki (9), C33A (9) and HeLa (9); pancreatic cancer cell lines, such as PANC-1 $(12,13)$, SW1990 $(12,13)$, CAPAN-1 $(12,13)$ and CAPAN-2 
(14); non-small cell lung cancer cell line, such as A549 $(8,11)$; prostate cancer cell line, such as $\operatorname{LNCaP}(9)$; hepatic cancer cell line, such as Hep3B (11); oesophageal cancer cell line, such as SLMT-1 (11); bladder cancer cell line, such as T24 (15); colon cancer cell line, such as HCT116 (16); oral cancer cell lines, such as KB (17) and ORL-48 (17). All reports showed that $B$. javanica extract was cytotoxic for cancer cell lines.(8-17)

$B$. javanica extract was shown to have several mechanisms in inducing cell death. $(9,11-15)$ Apoptosis induction by $B$. javanica extract was reported, in both p53-dependent and -independent pathways.(9) B. javanica extract was also reported to induce apoptosis through caspase cascade.(11-15) The activated caspases were correlated with p38 mitogen-activated protein kinases (MAPK) (13), B cell lymphoma 2 (BCL2) (14), Cyclooxygenase 2 (COX-2) (15) and nuclear factor $\kappa \mathrm{B}(\mathrm{NF} \kappa \mathrm{B})(15)$.

Most of investigated $B$. javanica extracts were derived from seeds and fruits, or commercially available oil emulsion.(8,9,11-16) However, other parts of B. javanica are also resourceful, like leaves, twigs, fruits and stems.(1) However, these parts were not well investigated, only one report showing active compounds of $B$. javanica extract derived from twigs, leaves and and inflorescence.(10) Therefore we conducted a study on $B$. javanica leaf extract (BJLE). We hypothesized that BJLE have a potential in apoptosis induction in oral cancer cells.

\section{Methods}

\section{Plant Extraction}

B. javanica leaves were collected from West Kutai, East Borneo. The leaves were identified and extracted in Mulawarman University. Briefly, the leaves were minced and dried at room temperature. The dried material was extracted with distilled ethanol at room temperature for 24 hours, filtered and then evaporated using rotatory evaporator to produce crude ethanol extract of B. javanica. Resulted BJLE was stored at $4^{\circ} \mathrm{C}$.

\section{Cell Culture}

Human oral squamous cell carcinoma (HSC)-2 cells were cultured in Dulbecco's Modified Eagle's Medium (DMEM) with high glucose (Sigma Aldrich, St. Louis, MO, USA), supplemented with $10 \%$ fetal bovine serum (FBS) and $1 \%$ penicillin-streptomycin. HSC-2 cells were incubated in a humidified incubator with $5 \% \mathrm{CO} 2,37^{\circ} \mathrm{C}$.

\section{Cell Viability}

Cell viability was performed using 3-(4,5-dimethylthiazol2-yl)-2,5-Diphenyltetrazolium bromide (MTT) assay (Sigma) as described previously.(18,19) The MTT assay provides a quantitative measurement of viable HSC-2 cells by determining the amount of formazan crystals produced by metabolically active cells. Briefly, $1 \times 10^{4}$ cells were seeded into each well of 96-well plates in medium containing active agent, hydrogen peroxide $\left(\mathrm{H}_{2} \mathrm{O}_{2}\right)$ or medium merely. Cells were incubated for 24 hours. Ten $\mu 1$ of $5 \mathrm{mg} / \mathrm{ml}$ MTT in phosphate buffer saline (PBS) was added to each well. The plate was then incubated for 4 hours, and then the medium was discarded and formazan crystals were dissolved in 100 $\mu \mathrm{l}$ of $0.1 \mathrm{~N} \mathrm{HCl}$. The absorbance of cells was measured at $570 \mathrm{~nm}$ by a microplate reader.

\section{4',6'-diamidino-2-phenylindole (DAPI) Staining}

DAPI staining was performed as described previously. $(20,21)$ HSC-2 cells were seeded onto coverslips, treated with BJLE, and fixed with $50 \%, 70 \%, 90 \%$, and $99.5 \%$ ethanol for 3 minutes. After washed in PBS, the fixed HSC-2 cells were treated with $0.1 \%$ BSA and $0.1 \%$ Triton $\mathrm{X}-100$ for 5 minutes. The cells were stained by applying 1:150 diluted DAPI (Calbiochem, San Diego, CA, USA) for 5 minutes. Then, the coverslips were rinsed with PBS, mounted with glycerol, and evaluated under fluorescence microscope.

\section{Mitochondrial membrane potential $(\Delta \Psi M)$ analysis} $\Delta \Psi \mathrm{M}$ was performed as described previously. $(20,21)$ After treatment with BJLE, cells were harvested and suspended in $250 \mu \mathrm{l}$ of $20 \mathrm{nM} \mathrm{3,3'-Dihexyloxacarbocyanine} \mathrm{Iodide}$ $\left(\mathrm{DiOC}_{6}\right)$ in PBS and incubated in an incubator for 15 minutes. $\triangle \Psi \mathrm{M}$ was measured using a FACSCanto II flow cytometer (Becton Dickinson, Franklin Lakes, NJ, USA).

\section{Results}

\section{BJLE reduced percentage of viable HSC-2 cells}

With treatment of $0.0014 \% \mathrm{H}_{2} \mathrm{O}_{2}$ for 24 hours, percentage of viable HSC-2 cells were only 10.8 (Figure 1). Meanwhile with treatment of dimethyl sulfoxide (DMSO), there were $78 \%$ viable HSC-2 cells. Treatment of BJLE in various concentrations $(5,10,20$ and $50 \mu \mathrm{g} / \mathrm{ml})$, showed that cell viability percentage was decreased in BJLE concentration dependent manner $(85.8 \%, 82.2 \%, 69.2 \%, 49.4 \%$, respectively). 


\section{BJLE induced apoptosis in HSC-2 cells}

Nuclei of HSC-2 cells were stained with DAPI. Clear bluish round nuclei were observed in Figure 2A, showing healthy HSC-2 cells population. Meanwhile, with treatment of $50 \mu \mathrm{g} / \mathrm{ml}$ BJLE, fragmented nuclei were seen, marked by

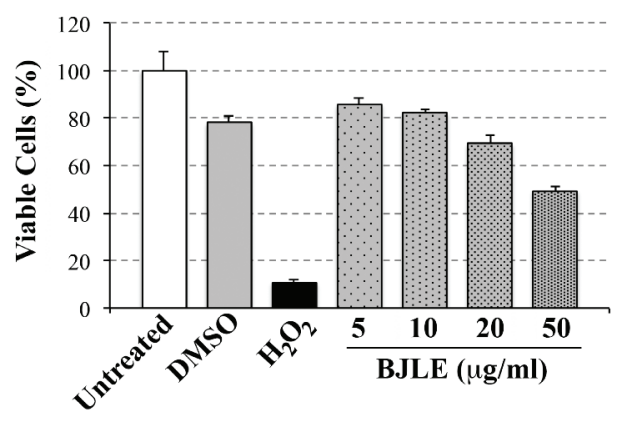

Figure 1. BJLE reduced percentage of viable HSC-2 cells. After HSC-2 cells were seeded and fasted for 12 hours, BJLE was added in various concentrations for 24 hours. Cells were quantified using MTT assay as described in "Method". For positive control, the cells were treated with $0.0014 \% \mathrm{H}_{2} \mathrm{O}_{2}$. DMSO was used as negative control, since BJLE was suspended in DMSO. Amount of DMSO as negative control was equaled to the amount of DMSO in $50 \mu \mathrm{g} / \mathrm{ml} \mathrm{BJLE}$.
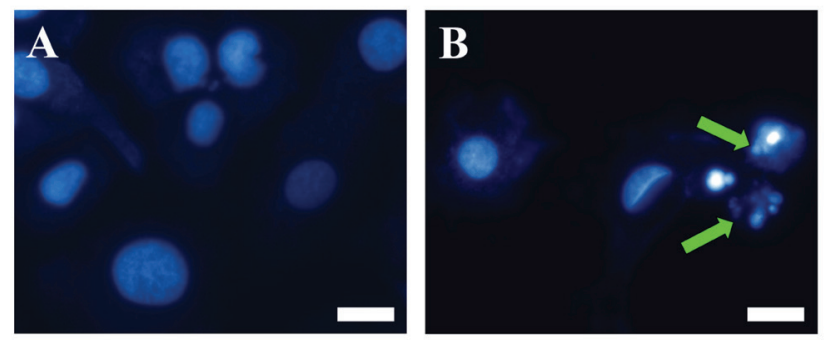

Figure 2. BJLE reduced percentage of viable $\mathrm{HSC}-2$ cells. After HSC-2 cells were seeded and fasted for 12 hours, $50 \mu \mathrm{g} / \mathrm{ml}$ BJLE was added for 24 hours (B). For negative control, the cells were treated with DMSO merely for 24 hours (A). Cell nuclei were demonstrated with DAPI staining as described in "Method". Red arrow: necrotic cell; Green arrow: apoptotic cells; White bar: 4 $\mu \mathrm{m}$.

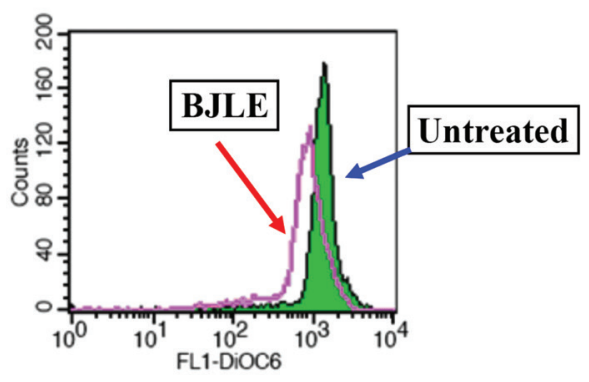

Figure 3. BJLE induced MMP. After HSC-2 cells were seeded and fasted for 12 hours, $50 \mu \mathrm{g} / \mathrm{ml}$ BJLE was added for 24 hours. MMP was measured using $\triangle \Psi M$ analysis as described in "Method". green arrow (Figure 2B). Cells with fragmented nuclei were apoptotic cells.

\section{BJLE attenuated mitochondrial membrane permeability (MMP)}

Recorded $\triangle \Psi M$ in untreated HSC-2 cells were labeled by DiOC6, observed and marked as green area. $\triangle \Psi M$ of HSC2 cells treated with $50 \mu \mathrm{g} / \mathrm{ml} \mathrm{BJLE}$ were shifted to the left, marked by purple line (Figure 3). This meant BJLE induced reduction of $\triangle \Psi \mathrm{M}$ and attenuation of MMP.

\section{Discussion}

B. javanica fruit and seed-derived extracts or commercially available oil emulsion have been investigated.(8,9,11-16) Currently, we investigated on BJLE as another possible potential source for anti-cancer agent. We found that treatment of BJLE reduced cell viability percentages in BJLE concentration dependent manner. Cell viability reduction was caused by apoptosis induction by BJLE, demonstrated as fragmented nuclei. Our results were in concordance to previous reports showing that $B$. javanica fruit and seed extracts induced apoptosis.(9,11-17)

$B$. javanica extract was mostly reported to induce apoptosis through caspase cascade.(11-15) B. javanica seed extract was shown to activate caspase 3,8 and 9 (1115) These caspases were correlated with mitochondrial apoptotic pathway. Therefore, BCL2 family was involved in this pathway $(13,14)$, which then lead to attenuation of MMP.(14) Our results showed that MMP of HSC-2 cells was attenuated by treatment of BJLE. Upon MMP attenuation, $\Delta \Psi \mathrm{M}$ will be disrupted, then apoptotic factor, such as cytochrome-c, will be released to cytoplasm. Other reported apoptotic mechanisms were p38-MAPK (13), COX-2 (15), and NFKB (15).

Combined with chemotherapy, B. javanica extract could improve quality of life in non-small cell lung cancer (NSCLC) patients without any increase in toxicity.(22) $B$. javanica oil emulsion (BJOE) combined with chemotherapy could be considered as a safe and effective regimen in treating patients with advanced gastric cancer (23) and advanced lung adenocarcinoma $(24,25)$. BJOE can improve the quality of life and reduce the possibility of some adverse effects. $(24,25)$ BJLE could also be important in treating cancer patient, therefore further study should be pursued. Taken together, our results suggested that BJLE could induce apoptosis by attenuating MMP. Further studies are necessary to explore BJLE mechanism, safety and efficacy. 


\section{References}

1. Zhao L, Li C, Zhang Y, Wen Q, Ren D. Phytochemical and biological activities of an anticancer plant medicine: Brucea javanica. Anticancer Agents Med Chem. 2014; 14: 440-58.

2. Bawm S, Matsuura H, Elkhateeb A, Nabeta K, Subeki, Nonaka N, et al. in vitro antitrypanosomal activities of quassinoid compounds from the fruits of a medicinal plant, Brucea javanica. Vet Parasitol. 2008; 158: 288-94.

3. Wu T, Abudou M, Chen S. Evidence-based anticancer materia medica for esophageal cancer. In: Cho WCS, editor. Materia Medica for Various Cancers. New York: Springer; 2012. p.151-70.

4. Zhang H, Yang JY, Zhou F, Wang LH, Zhang W, Sha S, et al. Seed oil of Brucea javanica induces apoptotic death of acute myeloid leukemi cells via both the death receptors and the mitochondrialrelated pathways. Evid Based Complement Alternat Med. 2011; 2011: 1-14.

5. Wang F, Qin W, Zhang G, Zhang Y, Liu H, Yang L, et al. Prospective clinical studies at the efficacy of Brucea javanica oil, mitomycin and BCG for preventing postoperative relapse of superficial bladder cancer through perfusion. China-German J Clin Oncol. 2011; 10: 228-31.

6. Cui Y, Wu Z, Liu X, Ni R, Zhu X, Ma L, et al. Preparation, safety, pharmacokinetics, and pharmacodynamics of liposomes containing Brucea javanica oil. AAPS PharmSciTech. 2010; 11: 878-84.

7. Yu YL, Lu Y, Tang X, Cui FD. Formulation, preparation and evaluation of an intravenous emulsion containing Brucea javanica oil and Coix Seed oil for anti-tumor application. Biol Pharm Bull. 2008; 31: 673-80.

8. Su Z, Hao J, Xu Z, Huang R, Zhang N, Qiu S. A new quassinoid from fruits of Brucea javanica. Nat Prod Res. 2013; 27: 2016-21.

9. Gao H, Lamusta J, Zhang WF, Salmonsen R, Liu Y, O’Connell E, et al. Tumor Cell Selective Cytotoxicity and Apoptosis Induction by an Herbal Preparation from Brucea javanica. N Am J Med Sci (Boston). 2011; 4: 62-6.

10. Pan L, Chin YW, Chai HB, Ninh TN, Soejarto DD, Kinghorn AD. Bioactivity-guided isolation of cytotoxic constituents of Brucea javanica collected in Vietnam. Bioorg Med Chem. 2009; 17: 221924.

11. Lau FY, Chui CH, Gambari R, Kok SH, Kan KL, Cheng GY, et al. Antiproliferative and apoptosis-inducing activity of Brucea javanica extract on human carcinoma cells. Int J Mol Med. 2005; 16: 115762.

12. Lau ST, Lin ZX, Zhao M, Leung PS. Brucea javanica fruit induces cytotoxicity and apoptosis in pancreatic adenocarcinoma cell lines. Phytother Res. 2008; 22: 477-86.

13. Lau ST, Lin ZX, Liao Y, Zhao M, Cheng CH, Leung PS. Bruceine
$\mathrm{D}$ induces apoptosis in pancreatic adenocarcinoma cell line PANC1 through the activation of $\mathrm{p} 38$-mitogen activated protein kinase. Cancer Lett. 2009; 281: 42-52.

14. Liu L, Lin ZX, Leung PS, Chen LH, Zhao M, Liang J. Involvement of the mitochondrial pathway in bruceine D-induced apoptosis in Capan-2 human pancreatic adenocarcinoma cells. Int J Mol Med. 2012; 30: 93-9.

15. Lou GG, Yao HP, Xie LP. Brucea javanica oil induces apoptosis in T24 bladder cancer cells via upregulation of caspase-3, caspase-9, and inhibition of NF-kappaB and COX-2 expressions. Am J Chin Med. 2010; 38: 613-24.

16. Yan Z, Zhang B, Huang Y, Qiu H, Chen P, Guo GF. Involvement of autophagy inhibition in Brucea javanica oil emulsion-induced colon cancer cell death. Oncol Lett. 2015; 9: 1425-31.

17. Majid MZ, Zaini ZM, Razak FA. Apoptosis-inducing effect of three medicinal plants on oral cancer cells $\mathrm{KB}$ and ORL48. ScientificWorldJournal. 2014; 2014: 125353. doi: $10.1155 / 2014 / 125353$.

18. Widowati W, Tjandrawati M, Risdian C, Ratnawati H, Tjahjani $\mathrm{S}$, Sandra F. The comparison of antioxidative and proliferation inhibitor properties of Piper betle L., Catharanthus roseus [L] G. Don, Dendrophtoe petandra L., Curcuma mangga Val. extracts on T47D cancer cell line. Int Res J Biochem Bioinform. 2011; 1: 22-8.

19. Arung ET, Kusuma IW, Purwatiningsih S, Roh SS, Yang CH, Jeon $\mathrm{S}$, et al. Antioxidant activity and cytotoxicity of the traditional Indonesian medicine Tahongai (Kleinhovia hospita L.) extract. J Acupunct Meridian Stud. 2009; 2: 306-8.

20. Sandra F, Hendarmin L, Nakao Y, Nakamura N, Nakamura S. TRAIL cleaves caspase- $8,-9$ and -3 of AM-1 cells: a possible pathway for TRAIL to induce apoptosis in ameloblastoma. Tumour Biol. 2005; 26: 258-64.

21. Arung ET, Wicaksono BD, Handoko YA, Kusuma IW, Shimizu K, Yulia D, et al. Cytotoxic effect of artocarpin on T47D cells. J Nat Med. 2010; 64: 423-9.

22. Ji ZQ, Huang XE, Wu XY, Liu J, Wang L, Tang JH. Safety of Brucea javanica and cantharidin combined with chemotherapy for treatment of NSCLC patients. Asian Pac J Cancer Prev. 2014; 15: 8603-5.

23. Liu J, Huang XE, Tian GY, Cao J, Lu YY, Wu XY, et al. Phase II study on safety and efficacy of Yadanzi ${ }^{\circledR}$ (Javanica oil emulsion injection) combined with chemotherapy for patients with gastric cancer. Asian Pac J Cancer Prev. 2013; 14: 2009-12.

24. Lu YY, Huang XE, Cao J, Xu X, Wu XY, Liu J, et al. Phase II study on Javanica oil emulsion injection (Yadanzi $\mathbb{R}$ ) combined with chemotherapy in treating patients with advanced lung adenocarcinoma. Asian Pac J Cancer Prev. 2013; 14: 4791-4.

25. Nie YL, Liu KX, Mao XY, Li YL, Li J, Zhang MM. Effect of injection of brucea javanica oil emulsion plus chemoradiotherapy for lung cancer: a review of clinical evidence. J Evid Based Med. 2012; 5: 216-25. 